\title{
Antimicrobial Activity of Water-soluble Products Derived from Radish Mustard Oil and Identification of an Active Component therein
}

\author{
Yasushi Uda ${ }^{*}$, Hiroki Matsuoka*, Hideki Shima*, Hitomi Kumagami* \\ and Yasuhiko MAEDA* \\ Department of Bioproductive Science, Faculty of Agriculture, \\ Utsunomiya University, 350, Mine-cho, Utsunomiya-shi, 321
}

\begin{abstract}
Antimicrobial property of water-soluble products obtained by degradation of 4-methylthio-3-butenyl isothiocyanate, the pungent principle of radish, was studied using 5 Gramnegative and 5 Gram-positive bacteria, 5 yeasts, and 9 fungi. Two antimicrobial components were found in the water-soluble products, of which the major one was isolated and indentified to be 2-thioxo-3-pyrrolidinecarbaldehyde on the bases of UV, MS, ${ }^{1} \mathrm{H}-\mathrm{NMR}$ and ${ }^{13} \mathrm{C}-\mathrm{NMR}$ spectral data. The identified compound exhibited a prominent growth-inhibition on the fungi and Gram-positive bacteria. The inhibitory effect on the yeasts and Gramnegative bacteria except for Escherichia coli was the least among the tested microorganisms.
\end{abstract}

Our previous studies showed that 4-methylthio- $(E)-3-$ butenyl isothiocyanate (MTBI), the pungent principle of radish, has a strong antifungal property ${ }^{1)}$, but it is easily degraded in an aqueous medium ${ }^{233}$. On the basis of those observations, we presumed that the antifungal activity can be partly due to watersoluble degradation product(s) of MTBI. Although antimicrobial property of naturally occurring mustard oils is well known ${ }^{4)-8)}$, their use for food preservation is restricted to some extent due to their pungent flavor. If watersoluble and non-odorous product possessing antimicrobial property can be derivable from mustard oils, the restriction should be largely reduced. From the point of view, characterization of antimicrobial property of the watersoluble fraction from MTBI and identification of main antimicrobial product were conducted in the present study.

\section{Materials and Methods}

\section{Microorganisms}

Five Gram-negative (Escherichia coli ATCC 11775, Enterobacter cloacae ATCC 13047, Salmonella typhimurium ATCC 13311, Proteus vulgaris ATCC 6380, and Pseudomonas aeruginosa ATCC 9721), and 5 Gram-positive (Staphylococcus aureus S-6, Staphylococcus epidermidis ATCC 14990, Bacillus subtilis ATCC 6633, Bacillus cereus var. mycoides ATCC 11778, and Streptococcus faecalis RIMD 3116001) bacteria, provided by Kanagawa Prefectural Hygienic Institute, Yokohama were used. Yeasts used were Candida valida IFO 10318, Candida lactiscondensi IFO 1286, Debaryomyces hansenii IFO 0855, Hansenula anomala IFO 10213 and Zygosaccharomyces rouxii IFO 1615. Fungi used were Alternaria helianthi IFO 9089, Cladosporium colocasiae IFO 6698, Eurotium chevalieri IFO 4090, Mucor racemosus f. racemosus IFO 5403, Penicillium frequentans IFO 7919, Penicillium expansum IFO 8800, Penicillium martensii IFO 8142, Aspergillus candidus IFO 4311 and Aspergillus fumigatus IFO 7080. The yeasts and fungi were obtained from the Institute for Fermentation, Osaka.

Assay for antimicrobial activity

The antimicrobial activity was measured as growth-inhibition zone of microorganisms using duplicate plates (i.d. $90 \mathrm{~mm}$ ). The bacterial strains were grown with shaking in $1 \mathrm{~m} l$ of Soybean-Casein Digest Broth (Daigo) at $37^{\circ} \mathrm{C}$ for $7 \mathrm{~h}$. Then, $0.2 \mathrm{~m} l$ portion mixed 
with $2 \mathrm{~m} l$ of $0.6 \%$ top agar was layered on Soybean-Casein Digest Agar (Daigo) plate $(\mathrm{pH}$ 5.0). The yeasts and fungi from stock cultures were seeded in $0.5 \mathrm{~m} l$ of sterilized water, of which $0.2 \mathrm{~m} l$ portion was mixed with $2 \mathrm{~m} l$ of $0.6 \%$ top agar. Then, the yeast-seeded top agar poured on a Y-1 agar plate ( $\mathrm{pH} 5.0$ ) composed of $0.3 \%$ yeast-extract, $0.3 \%$ maltextract, $0.5 \%$ peptone, $1.0 \%$ glucose and $2.0 \%$ agar, and the fungus-seeded top agar was layered on a malt-extract agar plate ( $\mathrm{pH} 5.0)$ composed of $2.0 \%$ malt-extract, $0.1 \%$ peptone, $2.0 \%$ glucose and $2.0 \%$ agar. The sample dissolved in $25 \mu \mathrm{l}$ dimethylsulfoxide (DMSO) was put on a paper disk $(10 \mathrm{~mm}$ diameter $)$, which was then placed on the agar surface seeded with the microbes. The bacteria were grown at $37^{\circ} \mathrm{C}$ for $24 \mathrm{~h}$, and the yeasts and fungi were cultivated at $25^{\circ} \mathrm{C}$ for $72 \sim 96 \mathrm{~h}$. Diameter of the growth-inhibition zones was measured after the cultivation. Potassium sorbate $(250 \mu \mathrm{g} /$ plate $)$ was used as a positive control.

Preparation of the water-soluble prouduct from MTBI

MTBI was prepared and purified from radish seedlings $(6 \mathrm{~kg})$ by the method previously described $^{3)}$. The purified MTBI consisting of $2.8 \sim 3.2 \mu \mathrm{mol}(Z)$-isomer and $17.2-18.5 \mu \mathrm{mol}$ (E)-isomer was mixed with $2.5 \mathrm{ml}$ of $0.1 \mathrm{M}$ phosphate buffer (pH 3.5 6.5). After shaking the mixture at $37^{\circ} \mathrm{C}$ for $120 \mathrm{~min}$, residual MTBI was removed with ethyl ether, and the aqueous layer was freeze-dried. The freeze-dried product was stored at $-30^{\circ} \mathrm{C}$ until use.

Chromatographic separation of the antimicrobial components

(1) Extrelut column chromatography

The Freeze-dried product $(25 \sim 30 \mathrm{mg})$ was dissolved in $20 \mathrm{ml}$ of distilled water, and adsorbed on an Extrelut (Cica-Merck, Tokyo) column $(20 \times 250 \mathrm{~mm})$. After standing for 20 min, the column was eluted with $80 \mathrm{ml}$ of chloroform-methanol (85:15) mixture. After the solvent was evaporated, the residue was used for the antimicrobial assay and further purification.

(2) Preparative HPLC
Preparative HPLC was carried out on a LiChrosphere RP-18 column $(10 \times 250 \mathrm{~mm})$ using $5 \%$ acetonitrile in $0.05 \mathrm{M}$ phosphate buffer ( $\mathrm{pH} 6.8)$ as a mobile phase. Separation was monitored at $265 \mathrm{~nm}$ with a UV detector (Shimadzu 6 AD).

\section{(3) Toyopearl column chromatography}

Antimicrobial fraction (15 20 mg) obtained by the Extrelut column chromatography was separated on a Toyopearl HW-40 S (Tohso Co., Tokyo) column $(15 \times 300 \mathrm{~mm})$. Distilled water was used as an eluent, and each $2.5 \mathrm{~m} l /$ tube of eluate was collected. Separation was monitored by UV absorption at $265 \mathrm{~nm}$.

(4) Chromatorex column chromatography

The antimicrobial fraction eluted from the Toyopearl column was rechromatographed on a reverse phase silica gel, Chromatorex DM 1020 $\mathrm{T}$ (Fuji-Davison Chemical Ltd., Kasugai) column $(12 \times 300 \mathrm{~mm})$, using $2 \%$ acetonitrile in distilled water as an eluent. Separation and detection of the antimicrobial product were made by the same manner as in the Toyopearl column chromatography.

\section{Instrumental analyses}

HPLC analysis was performed on a Shimadzu LC-6 AD with a UV detector. A LiChrosorb RP-18 column $(4 \times 150 \mathrm{~mm})$ was employed with a mobile phase of $5 \%$ acetonitrile in $0.05 \mathrm{M}$ phosphate buffer ( $\mathrm{pH} 6.8$ ). UV spectrum was measured with a Hitachi 330 spectrophotometer in distilled water. Mass spectrum was recorded on a Hitachi M-80 gas chromatograph-mass spectrometer at an ionization energy of $70 \mathrm{eV}$. ${ }^{1} \mathrm{H}-(300 \mathrm{MHz})$ and ${ }^{13} \mathrm{C}-\mathrm{NMR}$ $(75 \mathrm{MHz})$ spectra were recorded on a Varian VXR-300 nmr spectrometer in DMSO-d 6.

\section{Results and Discussion}

Antimicrobial activity of the water-soluble product

The water-soluble product prepared at $\mathrm{pH} 6.5$ was subjected to the assay for growth-inhibitory effect on the 20 microorganisms at 300 $\mu \mathrm{g} /$ plate dose. Table 1 shows the results along with the effect of potassium sorbate. The water-soluble product exhibited most prominent growth-inhibition on the fungi. The 
Table 1 Antimicrobial activity of the water-soluble fractions obtained by degradation of MTBI

\begin{tabular}{|c|c|c|}
\hline \multirow[b]{2}{*}{ Microorganism } & \multicolumn{2}{|c|}{ Growth-inhibition zone $(\%)^{\mathrm{a}}$} \\
\hline & $\begin{array}{c}W^{\left.W F^{b}\right)} \\
(300 \mu \mathrm{g})\end{array}$ & $\begin{array}{c}K \text {-sorbate }{ }^{c)} \\
(250 \mu \mathrm{g})\end{array}$ \\
\hline \multicolumn{3}{|l|}{ (Gram-negative bacteria) } \\
\hline Enterobacter cloacae & 2.3 & 4.5 \\
\hline Escherichia coli & 2.2 & 2.2 \\
\hline Proteus vulgaris & 2.4 & 17.8 \\
\hline Pseudomonas aeruginosa & 0 & 4.5 \\
\hline Salmonella typhimurium & 2.2 & 4.4 \\
\hline \multicolumn{3}{|l|}{ (Gram-positive bacteria) } \\
\hline Bacillus cereus & 13.2 & 22.1 \\
\hline Bacillus subtilis & 6.7 & 9.0 \\
\hline Staphylococcus aureus & 8.9 & 13.5 \\
\hline Staphylococcus epidermidis & 16.8 & 18.2 \\
\hline Streptococcus faecalis & 4.5 & 24.3 \\
\hline \multicolumn{3}{|l|}{ (Yeasts) } \\
\hline Debaryomyces hansenii & 6.7 & 11.2 \\
\hline Hansenula anomala & 0 & 15.6 \\
\hline Zygosaccharomyces rouxii & 6.8 & 17.8 \\
\hline Candida lactiscondensi & 0 & 26.7 \\
\hline Candida valida & 6.7 & 40.1 \\
\hline \multicolumn{3}{|l|}{ (Fungi) } \\
\hline Alternaria helianthi & 82.2 & 57.8 \\
\hline Cladosporium colocasiae & 66.8 & 53.6 \\
\hline Eurotium chevalieri & 72.3 & 68.9 \\
\hline Mucor racemosus & 13.4 & 24.6 \\
\hline Penicillium frequentans & 11.5 & 31.4 \\
\hline
\end{tabular}

a) Calculated by the equation DS/DP $\times 100=\%$ inhibition zone, where DS is the difference in diameters of the growth-inhibition zone between the control plates and the treated plates, and DP is the internal diameter of the used plates.

b) The water-soluble fraction from MTBI.

c) Potassium sorbate.

antifungal activities toward $A$. helianthi, $C$. colocasiae and $E$. chevalieri were higher than those revealed by $250 \mu \mathrm{g} /$ plate dose of potassium sorbate. Also, clear inhibitory effect on the growth of the Gram-positive bacteria and some yeasts was observed, where a comparatively higher growth-inhibition was observed toward $S$. epidermidis and B. cereus. The least influence was exhibited on the Gramnegative bacteria. From these results, it was ascertained that the water-soluble fraction obtained by degradation of MTBI has a prominent antifungal property.

Antimicrobial components in the watersoluble product

It was found that the Extrelut-eluted fraction from the water-soluble fraction prepared by degradation of MTBI at $\mathrm{pH} 6.5$ was clearly antifungal on both $C$. colocasiae and $E$. chevalieri. Then, composition of the Extreluteluted fraction was analyzed by the HPLC analysis. Figure 1 shows the HPLC-trace, in 
which four major peaks (P1, P2, P3 and P4) were detected. In order to determine the antifungal components, the four components were separated by the preparative HPLC. The components P1, P2 and P4 were successfully separated, though P3 was obtained as a mixture with nearly equal amount of P2. On the basis of peak areas in HPLC traces, concentrations of these four preparations were adjusted to nearly equal each other using DMSO as a solvent, and then they were assayed for antifungal activity on $C$. colocasiae and $E$. chevalieri. P1 fraction and P3-containing fraction were found to be antifungal on both fungi, but little antifungal activity was observed with $\mathrm{P} 2$ and $\mathrm{P} 4$ fractions. From the results, it was suggested that the antimicrobial property of the water-soluble product was possibly attributed to the components, $\mathrm{P} 1$ and P3.

Effect of $p H$ on the formation of the antimicrobial components

The water-soluble products prepared at different $\mathrm{pH}(3.5-6.5)$ were fractionated by the Extrelut column chromatography. The eluates were subjected to the HPLC analysis. Figure 2 shows the effects of $\mathrm{pH}$ on the change in the

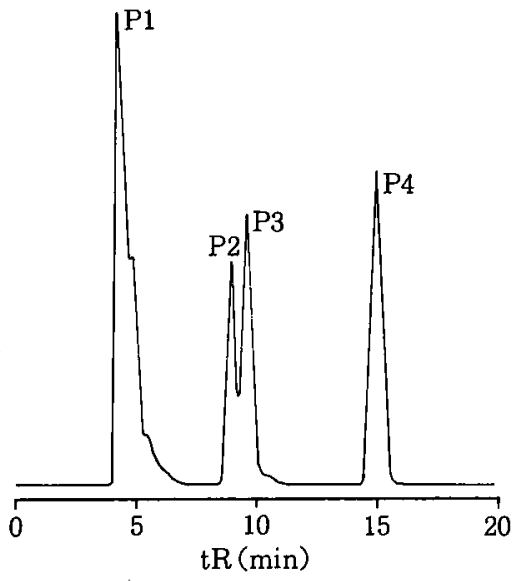

Fig. 1 HPLC separation profile of the Extrelut-eluted fraction from the water-soluble product obtained by degradation of MTBI at $\mathrm{pH} 6.5$

The analytical conditions were detailed in the text. amounts of the components, P1, P2, P3 and P4. With increase in $\mathrm{pH}$ of the degradation mixture, relative amount of P1 was increased, whereas another antifungal component, $\mathrm{P} 3$ was decreased. Thus, it was confirmed that P1 is favorably formed in a neutral aqueous medium, but P3 is easy to be formed in an acidic condition. Although the data are not shown here, the antifungal activity was observed within 30 min of the degradation at $\mathrm{pH} 6.5$, and reached to a maximum after 120 min.

Purification and identification of P1 and its antimicrobial property

The Extrelut column-eluting fraction containing P1, P2, P3 and P4 was subjected to the Toyopearl HW-40 column chromatography. As shown in Fig. 3, one major and some minor peaks were detected, whose HPLC analysis showed that P1 was contained in the major peak. Another antifungal P3 was not detected in any fraction, indicating that the component, P3 could not be eluted from the Toyopearl column under the employed chromatographic conditions. Then, the P1-containing major peak (fraction no. $12 \sim 22$ ) was further purified

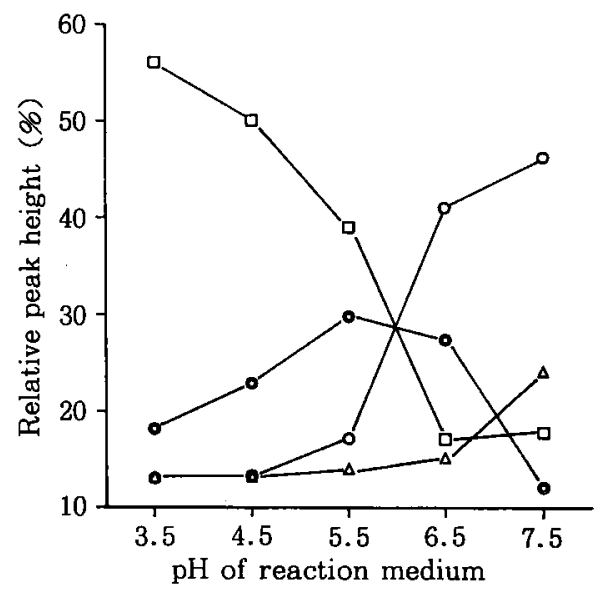

Fig. 2 Effect of $\mathrm{pH}$ on the formation of $\mathrm{P1}$ (O), P2 $(\triangle)$, P3 $(\square)$ and P4 (O) in the water-soluble degradation product of MTBI

The relative peak heights were calculated from the HPLC-traces of the degradation products. 


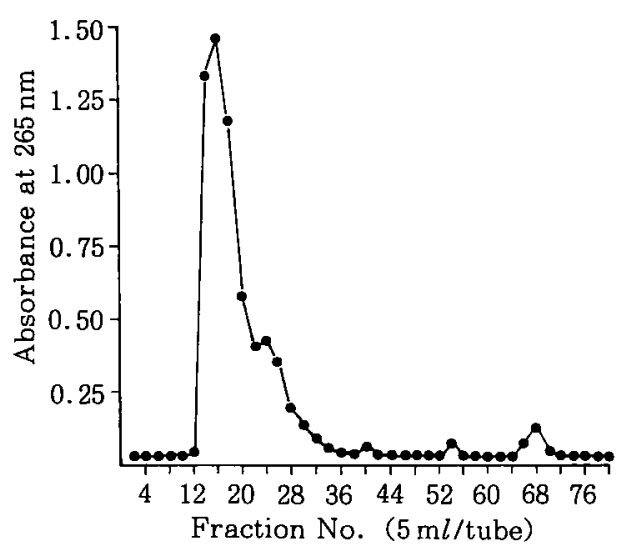

Fig. 3 Separation profile of the antifungal fraction from Extrelut column chromatography on a Toyopearl HW-40 column

Distilled water was used for elution.

by the Chromatorex column chromatography, which gave P1 with a purity of about $96 \%$. Figures 4 and 5 show the UV and MS spectra of the isolated $\mathrm{P} 1$. The ${ }^{1} \mathrm{H}-\mathrm{NMR}$ and ${ }^{13} \mathrm{C}-$ NMR spectral features of the isolated $\mathrm{P} 1$ were : ${ }^{1} \mathrm{H}-\mathrm{NMR}$ (DMSO)ppm, $10.19[1 \mathrm{H}, \mathrm{NH}$, s], $9.60[1 \mathrm{H}, \mathrm{OH}-\mathrm{C}(6), \mathrm{s}], 7.52[1 \mathrm{H}, \mathrm{H}-\mathrm{C}(6), \mathrm{t}$, $\mathrm{J}=2.4 \mathrm{~Hz}], 3.41-3.50[2 \mathrm{H}, \mathrm{H}-(5), \mathrm{m}]$, and 2.66 $[2 \mathrm{H}, \mathrm{H}-(4), \mathrm{dt}, \mathrm{J}=6.3 \& 2.1 \mathrm{~Hz}] ;{ }^{13} \mathrm{C}-\mathrm{NMR}$ (DMSO)ppm, $195.16[2-\mathrm{C}, \mathrm{C}=\mathrm{S}], 150.10[6-\mathrm{C}$, $=\mathrm{CH}], 117.62[3-\mathrm{C},>\mathrm{CH}=], 45.72\left[5-\mathrm{C},>\mathrm{CH}_{2}\right]$ and $23.15\left[4-\mathrm{C},>\mathrm{CH}_{2}\right]$. These spectral data were almost identical to those of 2-thioxo-3pyrrolidinecarbaldehyde (TPC), which had been identified as the degradation product of $\mathrm{MTBI}^{3)}$, and hence, the antifungal component, P1 was identified to be TPC (Fig. 6).

Table 2 shows the antimicrobial property of TPC toward the selected microorganisms. Growth inhibitory effects were prominently exhibited on the fungi and Gram-positive bacteria at $170 \mu \mathrm{g} /$ plate (ca. $1.3 \mu \mathrm{mol} /$ plate) dose. In addition, TPC revealed clear growthinhibition on Gram-negative E. coli. In comparison of the results with those in Table 1 , the antibacterial effect of TPC at $170 \mu \mathrm{g}$ dose was much higher than that of whole watersoluble product at $300 \mu \mathrm{g}$ dose, but the antifungal activity of the same dose of TPC

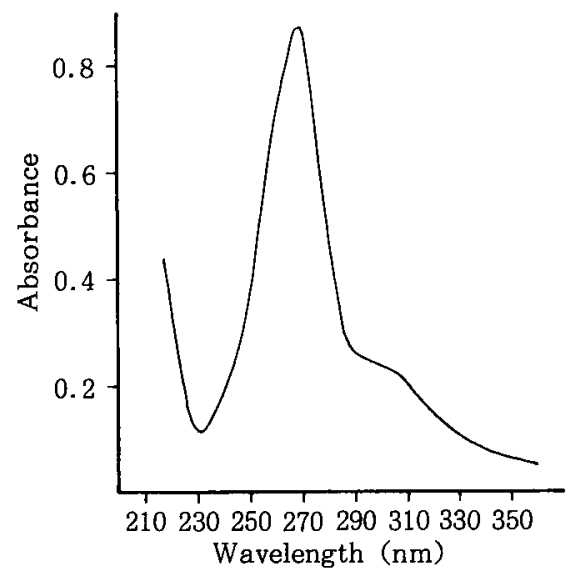

Fig. 4 UV spectrum of the antifungal component, $\mathrm{P} 1$

The spectrum was recorded in distilled water.

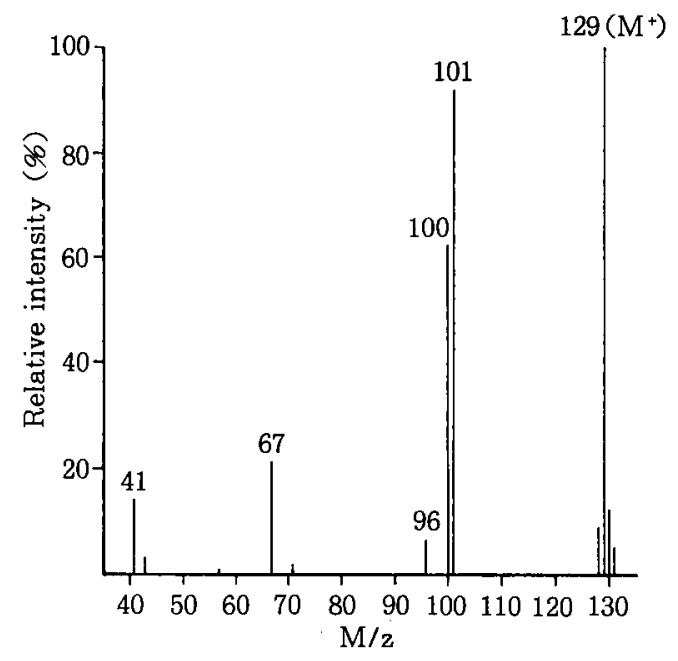

Fig. 5 Mass spectrum of the antifungal component, P1

The spectrum was recorded at $70 \mathrm{eV}$.<smiles>O/C=C1/CCNC1=S</smiles>

Fig. 6 Structure of TPC 
Table 2 Antimicrobial property of TPC

\begin{tabular}{|c|c|}
\hline Microorganism & $\begin{array}{c}\text { Growth- } \\
\text { inhibition } \\
\text { zone }(\%)^{a}\end{array}$ \\
\hline \multicolumn{2}{|l|}{ (Bacteria) } \\
\hline Escherichia coli & 19.7 \\
\hline Proteus vulgaris & 3.3 \\
\hline Salmonella typhimurium & 3.9 \\
\hline Bacillus cereus & 31.0 \\
\hline Bacillus subtilis & 22.4 \\
\hline Staphylococcus epidermidis & 35.1 \\
\hline \multicolumn{2}{|l|}{ (Yeasts) } \\
\hline Debaryomyces hansenii & 0 \\
\hline Hansenula anomala & 0 \\
\hline Zygosaccharomyces rouxii & 0 \\
\hline Candida valida & 6.9 \\
\hline \multicolumn{2}{|l|}{ (Fungi) } \\
\hline Alternaria helianthi & 47.6 \\
\hline Aspergillus candidus & 30.1 \\
\hline Aspergillus fumigatus & 0 \\
\hline Cladosporium colocasiae & 32.6 \\
\hline Eurotium chevalieri & 50.1 \\
\hline Mucor rasemosus & 26.9 \\
\hline Penicillium expansum & 0 \\
\hline Penicillium frequentans & 5.6 \\
\hline Penicillium martensii & 35.4 \\
\hline
\end{tabular}

a) Calculated by the equation denoted in the footnote in Table 1.

was lower. Thus, it was presumed that the amount of TPC in $300 \mu \mathrm{g}$ of the water-soluble product from MTBI was below $170 \mu \mathrm{g} /$ plate, and hence, another component, P3, contained in the water-soluble product, has a higher antifungal activity than TPC. This should be confirmed by further study.

Acknowledgement: We are grateful to Dr. Y. Onoue of Kanagawa Prefectural Hygienic Institute for his providing the bacterial strains.

\section{References}

1) Uda, Y., Matsuoka, H., Kumagami, H., Shima, H., Maeda, Y.: Nippon Shokuhin Kogyo Gakkaishi, 40, 743 (1993).

2) Ozawa, Y., Uda, Y., Ohshima, T., Saito,
K. and Maeda, Y.: Agric. Biol. Chem., 54, 605 (1990).

3) UdA, Y., OzaWA, Y., OHShima, T. and Kawakishi, S. : Agric. Biol. Chem., 54, 613 (1990).

4) KOser, O., Esselen, Jr., W. B. and FelleRs, C. R. : Food Res., 16, 510 (1951).

5) Virtanen, A. I. : Phytochemistry, 4, 207 (1965) .

6) EsaKI, H. and ONOZAKI, H.: Eiyo to Shokuryo, 35, 207 (1982).

7) NaKatani, N., IKeda, K., KiKuzaKi, H., KIDO, M. and YamaGuChI, Y.: Phytochemistry, 27, 3127 (1988).

8) Kanemaru, K. and Miyamoto, T. : Nippon Shokuhin Kogyo Gakkaishi, 37, 823 (1990).

(Received Apr. 27,1993)

\section{大根芥子油から誘導される水溶性生成物の抗菌活性 及び活性性分の同定 \\ 宇田 靖*・松岡寛樹* ・島 秀樹* 熊耳ひとみ*・前田安彦* \\ 宇都宮大学農学部生物生産科学科 （テ321 宇都宮市峰町 350）}

大根の主芥子油である4-メチルチオー3-ブテニルイン チオシアナート（MTBI）は水之接触して容易に分解す ることから，その水溶性分解生成物の抗菌活性を 5 種の グラム陰性細菌，5種のグラム陽性細菌，5種の酵母菌 及び 9 種の糸状菌を用いて検討した．その結果，同分解 生成物は特に，糸状菌及びグラム陽性細菌に対して顕著 な抗菌活性を有することが認められたが，グラム陰性細 菌及び醉母菌に対する抗菌活性は低かった，本水溶性分 解生成物をエキストレルート及び逆相-HPLCにより分 析した結果，4種の分解生成物が検出された。 そのうち， 2 種（P1，P3）が抗菌性を有し，P1 は $\mathrm{pH} \mathrm{6.5} \mathrm{7.5}$ の中性条件下で，P3 は pH 3.5 4.5 の酸性条件下で生 成し易いことが認められた，今回は中性条件下で生成し 易い P1 をトヨパール HW-40及びクロマトレックスを 用いるカラムクロマトグラフィーにより単離し, UV MS, NMR による同定を試みた。その結果，本成分は 既に MTBI の分解物として同定されている2-チオキ ソー3-ピロリジンカルバルデハイト（TPC）であった. 単離された TPC の抗菌活性を検定したところ, 系状菌 及びグラム陽性細菌に対して比較的顕著な抗菌活性が認 められた。 